\author{
Review Article \\ www.ijrap.net (ISSN:2229-3566)
}

\title{
ROLE OF STHAULYA IN THE DEVELOPMENT OF OBESE PCOS: A REVIEW
}

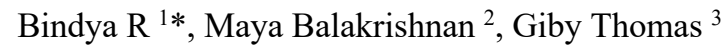

${ }^{1}$ PG Scholar, Department of Prasuti Tantra and Stree roga, Government Ayurveda College, Tripunithura, Kerala, India

${ }^{2}$ Professor and HOD, Department of Prasuti Tantra and Stree roga, Government Ayurveda College, Tripunithura, Kerala, India

${ }^{3}$ Associate Professor, Department of Prasuti Tantra and Stree roga, Government Ayurveda College, Tripunithura,

Kerala, India

Received on: 28/10/20 Accepted on: 25/11/20

\author{
*Corresponding author \\ E-mail: bindyabin@gmail.com
}

DOI: $10.7897 / 2277-4343.1106195$

\begin{abstract}
The polycystic ovarian syndrome is an extremely prevalent heterogeneous disorder affecting women in the reproductive age group. Symptoms may include menstrual irregularities, hyperandrogenism, or another endocrine dysfunction. Women with PCOS are more likely to be obese and are evident by their elevated BMIs and Waist: Hip ratios. These ratios reflect an android or central pattern of obesity which are the risk factors for cardiovascular disease one of the long-term consequences of PCOS. Obesity or sthoulya is a Santharpanajanya roga. Athisthoulyam is also mentioned under Ashtou ninditha purushas. An exact correlation of PCOS cannot be found in our classics; rather most clinical features are seen scattered among the symptoms and diseases mentioned in the context of Streeroga. Main menstrual irregularities seen in PCO women are oligomenorrhoea, amenorrhoea, and DUB which are found in the context of Artava Vyapat like Artavakshaya, Nashtartava, and Asrigdhara respectively. Anovulation resulting in amenorrhoea can be compared with Vandya yonivyapat and Pushpagni Jataharini.
\end{abstract}

Keywords: Sthaulya, Obesity, Obese PCOS

\section{INTRODUCTION}

The polycystic ovarian syndrome also known as Stein Leventhal syndrome is a multisystem endocrinopathy of women of reproductive age with the ovarian expression of various metabolic disturbances and a wide spectrum of clinical features such as obesity, menstrual abnormalities and hyperandrogenism ${ }^{1}$.

Obesity is a contributory factor of PCOS. The adipose tissue is considered as an endocrine and immunomodulatory organ that secretes leptin, adiponectin, and cytokines which interfere with insulin signaling pathways in the liver and muscle resulting in insulin resistance and hyperinsulinemia.

Obesity can worsen Hyperandrogenism by lowering Sex Hormone Binding Globulin (SHBG). A low level of SHBG can further cause an increase in the level of bioavailable testosterone. Thus, obesity has a synergetic effect on PCOS by worsening menstrual irregularities, hyperandrogenism, and other symptoms of PCOS.

An exact correlation for PCOS cannot be found in Ayurveda classics, rather its symptoms match with different gynecological conditions like Artavakshaya, Artavanasha and Asrigdhara that can be correlated to Oligomenorrhoea, amenorrhea and DUB respectively. Anovulation resulting in Nashtartava is explained in the context of Vandyayonivyapad ${ }^{2}$. Pushpagni Jataharini mentioned in Kashyapa Samhita has most resemblance with symptoms of PCOS which include fruitless menstrual cycles with fleshy and hairy cheek ${ }^{3}$.

Obesity can be correlated to Sthaulya mentioned as a Santharpanajanya Vyadhi ${ }^{4}$ by Acharya Charaka. He has also grouped "Ati sthaulya" among Ashtou Nindita Purusha ${ }^{5}$-that is eight undesirable constitutions. Fat distribution in the Sthoola is seen to concentrate on Sthana, Udara, and Sphik pradesa ${ }^{6}$ as in obese PCOS. According to him; Sthoola is more prone to develop Prameha $^{7}$; a variant of which is Type II diabetes which is seen in long-term PCOS. Dalhana in turn commented on Sushruta's Prameha Nidana as those women who have regular menstruation are less prone to Prameha ${ }^{8}$. This indicates that some women who were diagnosed with Prameha had irregular menstruation.

While considering the etiopathogenesis of Obese PCOS; the following Yoniroga Nidanas seem to be particularly significant. They are:

\section{Mithya Achara}

Mithyaachara can be Mithyaahara or Mithya vihara; improper practice in food and lifestyle.

\section{Mithya Ahara}

Acharya Charaka has mentioned excessive intake of Guru, Madhura, Seetha, and Snigdha Dravyas among the Nidanas of Athisthoulya ${ }^{9}$. This group of drugs in turn is Kapha dosha Prakopaka. These are comparable to excessive use of high-calorie foods like chocolates, ice-creams, and other junk foods leading to central obesity which is a part of modern food habits. Besides this Ruksha, Vishama, Sankeerna, Ajeerna, alpa, Pravridha Bhojana, leads to Vata Prakop ${ }^{10}$. People nowadays are habituated to the intake of dried and fried foods, eating before digestion of the food taken earlier, etc. Vatakapha dosha vitiation is mainly seen in obese PCOS. Acharya Susrutha has mentioned that etiology for sthoola or karsya is nothing other than disorders of rasa ${ }^{11}$; that is 
rasa dushti due to excess intake of non-congenial diet.

Most of the foods used in our busy world constitute Virudhaahara (incompatible foods). Virudhaahara causes an increase of Doshas in the body but are not being expelled out of the body and hence remain antagonistic to the Dhatus ${ }^{12}$. According to Charaka the ill effects produced by ingestion of Virudhaahara may affect the capacity of procreation (shaandya) or may be transmitted to the next generation ${ }^{13}$ : as in PCOS long term consequence of which is infertility.

\section{Mithya vihara}

Mithya vihara can be split out into Shareerika and Manasika. Stress is also known to alter the Hypothalamo pituitary compartment. Stress will cause the hypothalamus to signal on adrenal to produce more adrenaline and cortisol. Hypercortisolism can interfere with GnRH secretion. This may result in anovulation and amenorrhea. Suppression and forceful expulsion of natural urges, and mental states like fear, fright, sadness, grief, and excessive thought leads to Vata vitiation. Day sleep, laziness and sedentary habits, etc. lead to the vitiation of Kapha dosha. Avyayama and Diwaswapna are among the etiological factors mentioned in the context of Sthoulya ${ }^{14}$ Proper exercise provide lightness to the body, keen digestive power, depletion of medas ${ }^{15}$, etc. So those who lack adequate exercise will be afflicted by impaired Agni and Medo vrudhi. Besides in the context of Shroto dushti of Mamsavaha and Medovaha srothas, Avyayama and Diwaswapna are mentioned as the causative factors. In Manasika vikaras, Atichinta can cause Rasa Vaha Shroto dushti ${ }^{16}$. Thus a sedentary lifestyle along with excessive diet and psychological factors such as stress, anxiety, depression, etc. play a definite role in the pathology of PCOS.

\section{Concept of Agni and Ama}

The proper functioning of Agni helps in the maintenance of physiological activities in our body. When Agni is weak food that is incompletely digested results in the build-up of a toxic substance called Ama ${ }^{17}$. Acharya Vagbhata clarifies that it is not only ingestion of excess food or overeating that results in Ama dosha, other causes such as raw food (uncooked), food that cause distension of abdomen, heavy, dry, too cold, unclean and capable of causing Vidaha, dehydrated food and food soaked in too much of water can also cause Amadosha ${ }^{18}$. Besides these mental stresses such as rage, grief, etc may result in the development of Amadosha ${ }^{19}$. Ama may imbalance the normal homeostasis of the body thereby hindering the normal formation of Sthayi dhatus and further Dhatu Parinama. The formation of Ama is important in the pathogenesis of PCOS as it is now considered a metabolic syndrome resulting from an unhealthy lifestyle and eating habits.

\section{Beeja dosha}

Acharya Charaka has stated that during embryological development part of Beeja that gets affected in one way or other results in disease or dysfunction in the respective part of the individual ${ }^{20}$.

He has highlighted Beejaswabhava ${ }^{21}$ as one of the Nidanas of Athisthoola as well. Thus, Beeja dosha can be regarded as one of the important etiologic factors in the case of obese PCOS. In patients with PCOS, there are many clinical and in-vitro studies of human theca cells supporting the dysregulation of CYPII gene $^{22}$.

The pathogenesis of PCOS may be explained byan integrated genetic and epigenetic model, with environmental factors contribute to the development of PCOS by modifying the effects of susceptibility genes. Fetuses exposed to elevated androgens in utero later develop PCOS-like phenotypes as adults, including hyperandrogenism, oligomenorrhea, polyfollicular ovaries, increased adiposity, insulin resistance and impaired insulin secretion ${ }^{23}$. This phenomenon forms the basis of the fetal origins of the PCOS hypothesis. An interesting example supporting this is; when exogenous testosterone is administered to pregnant rhesus monkeys, the female offspring later on developed increased adiposity and altered insulin/glucose regulation, LH hypersecretion, ovarian and adrenal Hyperandrogenism, ovulatory dysfunction and polycystic ovaries ${ }^{24}$.

\section{Pradushta Artava}

The term Artava includes all the variables involved in the process of menstruation including ovum, steroid hormones and mechanisms involved in the regulation of the HPO axis. Vata Kapha vitiation leading to Artavavaha Shroto avarana can lead to Artava nasa ${ }^{25}$. This Avarana can also be impairment in pulsatile secretion of GnRH as seen in PCOS. Leptin; a peptide secreted by fat cells and by ovarian follicle also causes increased pulse frequency of $\mathrm{GnRH}$.

\section{DISCUSSION}

Ati sthaulya is grouped under eight undesirable constitutions. In sthaulya equilibrium of dhatus are disturbed as seen in PCOS presenting various metabolic disturbances. Atisampooranath ${ }^{26}$ (overeating), one of the Sthaulya nidanas is also relevant in the pathology of obese PCOS. GABA receptor modulating steroids stimulate food intake in the hypothalamic arcuate nucleus and paraventricular nucleus. Allopregnanolone is a potent positive GABA receptor modulating steroid (GAMS). Elevated allopregnanolone levels are associated with increases in food intake, preferences for energy-rich food, and obesity in humans. In women with PCOS high serum allopregnanolone ${ }^{27}$, concentrations are seen and are linked to uncontrolled eating. In obese PCOS etiological factors mentioned above are mostly kaphavrudhikara. These further results in Jataragni Mandhya and lead to the accumulation of Ama dosha. The formation of Artava considered as the Prasada bhaga of rasa is also impaired. Both Sama Kapha and Sama Rasa increase the Snigdhamsa of the body and causes Shrotorodha. This Sama rasa along with mental factors like excessive Soka, krodha, etc. finally leads to Vata vaigunya besides this in obese PCOS Medodushti augments the blockage of Srotas. Also, Medovaha Srotomoola (Kati) dushti results in the Sthanasamshraya of doshas at Kati Pradesha causing Apana Vaigunya to impair Artava Nishkramana. Vitiated Vata and Kapha may cause Avarana to Artavavaha Shrotas resulting in Artavanasha. The normal functions of Artava are Rakta lakshana and Garbhakrit ${ }^{28}$. The term "garbhakrit" may be considered to include ovulation. Impaired formation of Artava also disturbs normal ovulation. This may result in infertility a long-term sequelae of PCO. Dhatwagni derangement leads to a diminution of Dhatus and an increase in Dhatu Malas. Kesa and Loma are the Dhatumala of Asthi. This can relate to the development of hirsutism in women with PCO. An increase in Majja dhatu mala results in an increased amount of snehamsa of the body which is reflected as increased production of sebum which on vitiation by Doshas causes Mukha Dushika or acne. The increased unctuousness of the body affects the Agneya property of Pitta. Acharya Charaka has stated that the normal and abnormal color of the body is due to pitta ${ }^{29}$. Relative diminution of Pitta affects Prabha and Varnam which causes karshnyam.-Acanthosis Nigricans. Acanthosis nigricans is the dermal manifestation of hyperinsulinemia seen in PCOS. The vitiated Kapha affects Medo dhatu due to the common Panchamahabhuta constitution (Ap + 
Prithvi) leading to Santarpana janya Vyadhis like Prameha, as in the development of Type II Diabetes Mellitus in obese PCOS.

\section{CONCLUSION}

Changing lifestyle and eating habits of the modern era along with genetic factors contribute significantly to the development of PCOS in obese women. Polycystic Ovarian Syndrome now regarded as a metabolic syndrome can be managed to a large extent by following proper Ahara and Vihara. Equilibrium of doshas is attained by indulging in Hitakara Ahara and Vihara and this, in turn, results in the proper functioning of Agni. Proper functioning of Agni is essential for the adequate formation of Rasadhathu. Artava being the Upadhatu of Rasa will be then formed unvitiated.

\section{REFERENCES}

1. Howkins \& Bourne; Shaw's Text Book of Gynaecology; edited by Padubidri VG, Daftary SN; RELX India Private Limited; $6^{\text {th }}$ ed; 2015. p. 431.

2. Srikantamurty KR editor; Sushruta Samhita; Varanasi, Chaukhambha Orientalia; Uttara sthana, Chap-38, Shlok10-11; 2014. p. 171.

3. Tewari PV editor; Kashyapa Samhita; Varanasi; Chaukhambha Vishvabharati Oriental Publishers and Distributors; Revathi Kalpa Adhyaya, Shlok-33.2-34.1; 2013. p. 357.

4. Sharma Ram Karan, Dash B; Agnivesha's Charaka Samhita; Varanasi; Chaukhambha Sanskrit Series; Sutra sthana, Chap-23, Shlok-3-7; 2014. p. 395.

5. Sharma Ram Karan, Dash B. Agnivesha's Charaka Samhita; Varanasi; Chaukhambha Sanskrit Series; Sutra sthana, Chap-21, Shlok-3; 2014. p. 374.

6. Sharma Ram Karan, Dash B; Agnivesha's Charaka Samhita; Varanasi; Chaukhambha Sanskrit Series; Sutra sthana, Chap-21; 2014. p. 376.

7. Sharma Ram Karan, Dash B; Agnivesha's Charaka Samhita; Varanasi; Chaukhambha Sanskrit Series; Nidana Sthana, Chap-4, Shlok-48; 2015. p. 65.

8. Yadavji Trikamji; Nibandha sangraha Commentary of Sri Dalhanacharya; Varanasi; Chaukhambha Sanskrit Sansthan; Chikitsa sthana; Chap7, Shlok-3; 2014. p. 451.

9. Sharma Ram Karan Dash B; Agnivesha's Charaka Samhita; Varanasi; Chaukhambha Sanskrit Series; Sutra sthana, Chap-21, Shloka- 34; 2014. p. 374.

10. Srikantamurty KR; Vagbhata's Ashtanga Hridaya; Varanasi; Chaukhambha Krishnadas Academy; Nidana sthana; Chap-1, Shloka-14-15; 2013. p. 7,8.

11. Srikantamurty KR; Sushruta Samhita; Varanasi; Chaukhambha Orientalia; Chap-15, Shloka; 2014. p. 107.

12. Sharma Ram Karan, Dash B; Agnivesha's Charaka Samhita; Varanasi; Chaukhambha Sanskrit Series; Sutra sthana, Chap-26, Shloka-85; 2014. p. 485.

13. Sharma Ram Karan Dash B; Agnivesha's Charaka Samhita; Varanasi; Chaukhambha Sanskrit Series; Sutra sthana, Chap
-26, Shloka-102-103; 2014. p. 488

14. Sharma Ram Karan, Dash B; Agnivesha's Charaka Samhita; Varanasi; Chaukhambha Sanskrit Series; Sutra sthana, Chap-21, Shloka- 4; 2014. p. 374.

15. Srikantamurty KR; Vagbhata's Ashtanga Hridaya; Varanasi; Chaukhambha Krishnadas Academy; Sutra sthana; Chap-2, Shloka-10; 2011. p. 24

16. Sharma, Ram Karan Dash B; Agnivesha's Charaka Samhita; Varanasi; Chaukhambha Krishnadas Academy; Vimana sthana; Chap-5, Shloka-13; 2014. p. 178.

17. Srikantamurty K R; Vagbhata's Ashtanga Hridaya; Varanasi; Chaukhambha Krishnadas Academy; Sutra sthana; Chap-13, Shloka-25; 2011. p. 187.

18. Srikantamurty K R; Vagbhata's Ashtanga Hridaya; Varanasi; Chaukhambha Krishnadas Academy; Sutra sthana; Chap-8, Shloka-31; 2011. p. 130.

19. Srikantamurty K R; Vagbhata's Ashtanga Hridaya; Varanasi; Chaukhambha Krishnadas Academy; Sutra sthana; Chap-8, Shloka-32; 2011. p. 130.

20. Sharma Ram Karan, Dash B; Agnivesha's Charaka Samhita; Varanasi; Chaukhambha Krishnadas Academy; Shareera sthana; Chap-3, Shloka 17; 2014. p. 382.

21. Sharma Ram Karan, Dash B; Agnivesha's Charaka Samhita; Varanasi; Chaukhambha Sanskrit Series; Sutra sthana, Chap-21, Shloka- 4; 2014. p. 374.

22. Hoffman, Schorge, Schaffer, Halvorson, Bradshaw, Cunningham; editors. William's Gynaecology. $2^{\text {nd }}$ ed. United States. Mcgraw Hill companies; 2012. p. 461.

23. N Xu, S kwon, DH Abott, DH Geller DD. Epigenetic Mechanism Underlying the Development of Polycystic Ovary Syndrome (PCOS)- Like Phenotypes in Prenatally Androgenized Rhesus Monkeys. PLoS One; 2011.

24. Daniel A. Dumesic, David H. Abbott VP. Polycystic ovary Syndrome and its developmental origins. Springer. $15^{\text {th }}$ ed; 2007.

25. Srikantamurty K R; Sushruta Samhita; Varanasi; Chaukhambha Orientalia; Shareera sthana; Chap-2, Shloka21; 2014. p. 22.

26. Sharma Ram Karan, Dash B; Agnivesha's Charaka Samhita; Varanasi; Chaukhambha Sanskrit Series; Sutra sthana; Chap-21, Shloka- 4; 2014. p. 374.

27. Holmberg, S Josted S, Malinina U, Johansson U, Turkmen $\mathrm{S}$. Ragagin $\mathrm{S}$, et al. Allopregnanolone involvement in feeding regulation, overeating, and obesity. Science Direct 2018; 48: 70-7.

28. Srikantamurty KR; Sushruta Samhita; Varanasi; Chaukhambha Orientalia; Chap-15, Shloka-7; 2014. p. 99.

29. Sharma Ram Karan, Dash B; Agnivesha's Charaka Samhita; Varanasi; Chaukhambha Sanskrit Series; Sutra sthana; Chap-12, Shloka-11; 2014. p. 240.

\section{Cite this article as:}

Bindya R. et al. Role of Sthaulya in the development of Obese PCOS: A Review. Int. J. Res. Ayurveda Pharm. 2020;11(6):102104 http://dx.doi.org/10.7897/2277-4343.1106195 every effort has been taken to verify the accuracy of the content published in our Journal. IJRAP cannot accept any responsibility or liability for the site content and articles published. The views expressed in articles by our contributing authors are not necessarily those of IJRAP editor or editorial board members. 